\title{
Ficus carica L. (Moraceae): Phytochemistry, Traditional Uses and Biological Activities
}

\author{
Shukranul Mawa, Khairana Husain, and Ibrahim Jantan \\ Drug and Herbal Research Centre, Faculty of Pharmacy, Universiti Kebangsaan Malaysia, \\ Jalan Raja Muda Abdul Aziz, 50300 Kuala Lumpur, Malaysia \\ Correspondence should be addressed to Khairana Husain; khairana@pharmacy.ukm.my
}

Received 10 June 2013; Accepted 13 August 2013

Academic Editor: Angelo Antonio Izzo

Copyright (C) 2013 Shukranul Mawa et al. This is an open access article distributed under the Creative Commons Attribution License, which permits unrestricted use, distribution, and reproduction in any medium, provided the original work is properly cited.

\begin{abstract}
This paper describes the botanical features of Ficus carica L. (Moraceae), its wide variety of chemical constituents, its use in traditional medicine as remedies for many health problems, and its biological activities. The plant has been used traditionally to treat various ailments such as gastric problems, inflammation, and cancer. Phytochemical studies on the leaves and fruits of the plant have shown that they are rich in phenolics, organic acids, and volatile compounds. However, there is little information on the phytochemicals present in the stem and root. Reports on the biological activities of the plant are mainly on its crude extracts which have been proven to possess many biological activities. Some of the most interesting therapeutic effects include anticancer, hepatoprotective, hypoglycemic, hypolipidemic, and antimicrobial activities. Thus, studies related to identification of the bioactive compounds and correlating them to their biological activities are very useful for further research to explore the potential of $F$. carica as a source of therapeutic agents.
\end{abstract}

\section{Introduction}

Ficus (Moraceae) comprises one of the largest genera of angiosperms with more than 800 species of trees, shrubs, hemiepiphytes, climbers, and creepers in the tropics and subtropics worldwide [1]. This genus is an important genetic resource due to its high economic and nutritional values and also an important part of the biodiversity in the rainforest ecosystem. It is also a good source of food for fruit-eating animals in tropical areas [2]. The genus is divided into six subgenera based on preliminary morphology. The monoecious subgenus Urostigma is the largest with about 280 species all inclusive, and most of them display distinctive hemiepiphytic habits. Ficus includes 23 species of hemiepiphytes and lithophytes which produce aerial and creeping root systems [3].

F. carica L. is an important member of the genus Ficus. It is ordinarily deciduous and commonly referred to as "fig". The common fig is a tree native to southwest Asia and the eastern Mediterranean, and it is one of the first plants that were cultivated by humans. The fig is an important harvest worldwide for its dry and fresh consumption. Its common edible part is the fruit which is fleshy, hollow, and receptacle [4]. The dried fruits of $F$. carica have been reported as an important source of vitamins, minerals, carbohydrates, sugars, organic acids, and phenolic compounds [5-7]. The fresh and dried figs also contain high amounts of fiber and polyphenols $[8,9]$. Figs are an excellent source of phenolic compounds, such as proanthocyanidins, whereas red wine and tea, which are two good sources of phenolic compounds, contain phenols lower than those in fig [10]. Its fruit, root, and leaves are used in traditional medicine to treat various ailments such as gastrointestinal (colic, indigestion, loss of appetite, and diarrhea), respiratory (sore throats, coughs, and bronchial problems), and cardiovascular disorders and as anti-inflammatory and antispasmodic remedy [11, 12].

F. carica L. belongs to the order of Urticales and family of Moraceae with over 1400 species classified into about 40 genera [13]. A number of them are functionally female and produce only a seed-bearing fruit, whereas others are functionally male and produce only pollen and pollen-carrying wasp progeny [14-16]. The species of $F$. carica are shrubs or small trees and deciduous. Its roots are not adventitious, 
and the barks are grayish and slightly roughened. The leaves are stipulated and petiolated with obovate, nearly orbiculate or ovate leaf blade, palmately lobed, cordate base, undulate or irregularly dentate margin, acute to obtuse apex, and scabrous-pubescent surfaces [17].

F. carica has been cultivated for a long time in various places worldwide for its edible fruit. It is supposed to originate from Western Asia and spread to the Mediterranean by humans [18]. It is also an imperative world crop today. Turkey, Egypt, Morocco, Spain, Greece, California, Italy, Brazil, and other places with typically mild winters and hot dry summers are the major producers of edible figs [19]. Fruits can be eaten raw, dried, canned, or in other preserved forms [20].

F. carica possibly originated from the Middle East, which is one of the early cultivated fruit species [21] and currently is an important crop worldwide. Nowadays, the common fig still grows wild in the Mediterranean basin. Morphological data propose that the fig is gynodioecious, whereas from a functional standing point, the fig is considered dioecious with two tree morphs: Capri fig and edible fig. Habitual fig cultivation areas have significantly decreased, and genetic variability was reduced due to disappearance of many cultivars selected in the past. Actually almost all grown cultivars are the result of old selection and are maintained by cutting as a way of vegetative propagation [22].

The fruit (syconium or fig) and reproduction systems of species in the genus Ficus are exclusive. It can only be pollinated by their associated agaonid wasps (Hymenoptera: Chalcoidea: Agaonide), and in turn the wasps can only lay eggs within their associated fruit. For successful pollination and reproduction of species of $F$. carica to occur, its associated pollinator wasp must be present. Conversely, for successful reproduction of agaonid wasps to occur, their associated species of F. carica must be present [15]. The pollinator wasp for F. carica is Blastophaga psenes (L.) [23].

\section{Phytochemistry}

Phytochemical studies on F. carica revealed the presence of numerous bioactive compounds such as phenolic compounds, phytosterols, organic acids, anthocyanin composition, triterpenoids, coumarins, and volatile compounds such as hydrocarbons, aliphatic alcohols, and few other classes of secondary metabolites from different parts of $F$. carica (Figure 1). Most species of F. carica contain phenolic compounds, organic acids, and volatile compounds [24, 25].

Phenolic acids such as 3-O- and 5-O-caffeoylquinic acids, ferulic acid, quercetin-3-O-glucoside, quercetin-3-Orutinoside, psoralen, bergapten, and organic acids (oxalic, citric, malic, quinic, shikimic, and fumaric acids) have been isolated from the water extract of the leaves of F. carica L. [24]. Coumarin has been isolated from the methanol extract of the leaves of $F$. carica L. by bioassay-guided isolation, and the isolated coumarin exhibited the strongest nematicidal activity against the nematodes Bursaphelenchus xylophilus, Panagrellus redivivus, and Caenorhabditis elegans within $72 \mathrm{hr}$ [26]. Four triterpenoids, bauerenol, lupeol acetate, methyl maslinate, and oleanolic acid,have been isolated from the leaves of F. carica and showed irritant potential on mice ears [27].

The leaves of $F$. carica consist of various volatile compounds which are identified and distributed by distinct chemical classes, such as aldehydes: methylbutanal, 2-methylbutanal, (E)-2-pentanal, hexanal, and (E)-2-hexanal, alcohols: 1-penten-3-ol, 3-methyl-1-butanol, 2-methylbutanol, heptanol, benzyl alcohol, (E)-2-nonen-1-ol, and phenylethyl alcohol, ketone: 3-pentanone, esters: methyl butanoate, methyl hexanoate, hexyl acetate, ethyl benzoate, and methyl salicylate, monoterpenes: limonene and menthol, sesquiterpenes: $\alpha$-cubenene, $\alpha$ guaiene, $\alpha$-ylangene, copaene, $\beta$-bourbonene, $\beta$-elemene, $\alpha$-gurjunene, $\beta$-caryophyllene, $\beta$-cubebene, aromadendrene, $\alpha$-caryophyllene, $\tau$-muurolene, $\tau$-cadinene, $\alpha$-muurolene, germacrene $\mathrm{D}$, and $(+)$-ledene, norisoprenoid: $\beta$-cyclocitral, and miscellaneous compounds: psoralen [28].

Fifteen anthocyanin pigments were isolated from the fig fruit and bark of F. carica. Most of them contain cyanidin as aglycone and some pelargonidin derivatives [6]. Pentane extracts from the fig of $F$. carica contain numerous volatile compounds: benzyl aldehyde, benzyl alcohol, furanoid, linalool, pyranoid (trans), cinnamic aldehyde, indole, cinnamic alcohol, eugenol, and transcaryophyllenes sesquiterpene: germacrene $\mathrm{D}$, hydroxyl caryophyllene, angelicin, and bergapten [25].

Total and individual phenolic compounds, phenolic acid, chlorogenic acid, flavones, and flavonols, have been isolated from fresh and dried fig skins of $F$. carica and dried figs contained total higher amounts of phenolics than the pulp of fresh fruits, owing to the contribution of the dry skin. Quercetin rutinoside was the major individual phenolic [29] while microbial $\beta$ - $D$-glucans has been isolated from Libyan figs of $F$. carica [30].

Phenolic acids; 3-O- and 5-O-caffeoylquinic acids, ferulic acid, quercetin-3-O-glucoside, quercetin-3-O-rutinoside, psoralen, and bergapten, and organic acids (oxalic, citric, malic, shikimic, and fumaric acids) were isolated from the pulps and peels of figs [24]. Phenolics, anthocyanins, fructose, glucose, and sucrose were identified from the fig of F. carica [31].

Various volatile constituents of five Portuguese varieties of F. carica fruits (pulps and peels) have been isolated which include aldehydes: 3-methyl-butanal, 2-methylbutanal, (E)-2-pentanal, hexanal, heptanal, octanal, and nonanal, alcohols: 1-penten-3-ol, 3-methylbutanol, benzyl alcohol, (E)-2-nonenol, and phenylethyl alcohol, ketone: 6-methyl-5-hepten-2-one, esters: methyl hexanoate, methyl salicylate, and ethyl salicylate, monoterpenes: limonene, menthol, $\alpha$-pinene, $\beta$-pinene, linalool, eucalyptol, sesquiterpenes: $\alpha$-cubenene, copaene, $\beta$-caryophyllene, $\tau$-muurolene, $\tau$-cadinene, and germacrene $\mathrm{D}$, norisoprenoid: $\beta$-cyclocitral, and miscellaneous compounds: eugenol [28].

\section{Traditional and Current Uses}

F. carica has been traditionally used for its medicinal benefits as metabolic, cardiovascular, respiratory, antispasmodic, and 
<smiles>COc1cc(/C=C/C(=O)O)ccc1O</smiles><smiles>C=C1C=Cc2cc3ccoc3cc2O1</smiles>

Quercetin-3-O-glucoside (4)

Quercetin-3-O-rutinoside (5)<smiles>COc1c2ccoc2cc2oc(=O)ccc12</smiles>

Bergapten (7)<smiles>O=c1ccc2ccccc2o1</smiles>

Coumarin (8)

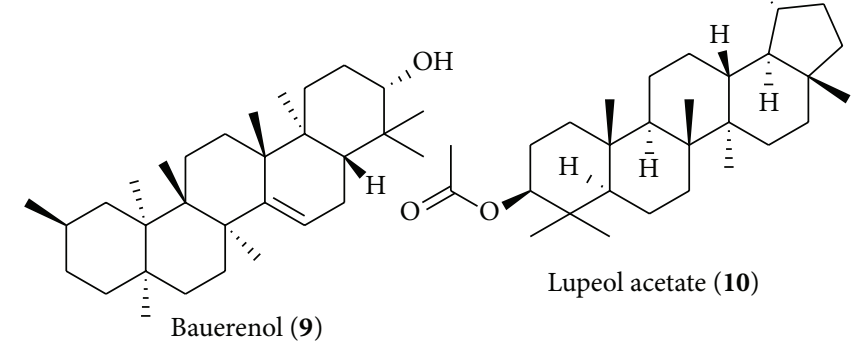

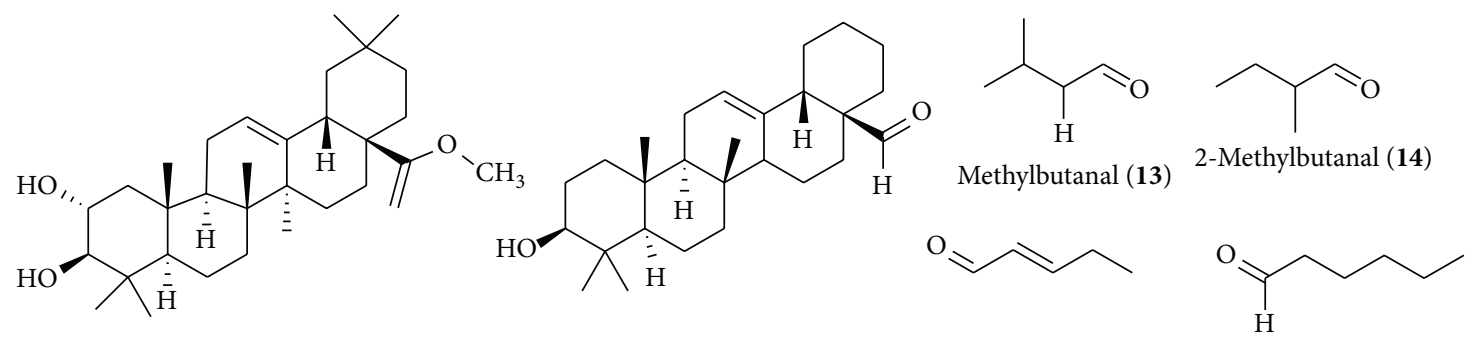

Methyl maslinate (11)

Oleanolic acid (12)

(E)-2-Pentanal (15)

Hexanal (16)<smiles>C=CC(O)CC</smiles>

(E)-2-Hexanal (17)

1-Penten-3-ol (18)<smiles>CCC(C)CO</smiles>

2-Methylbutanol (20)<smiles>CCCCCCCO</smiles>

Heptanol (21) 3-Methylbutanol (19)<smiles>OCc1ccccc1</smiles>

Benzyl alcohol (22)<smiles>CCCCCCC=CCO</smiles>

(E)-2-Nonenol (23)<smiles>OCCC1CCCCC1</smiles><smiles>CCC(=O)CC</smiles>

3-Pentanone (25)<smiles>CCCC(=O)OC</smiles>

Methyl butanoate (26)

Phenylethyl alcohol (24)

(a)

Figure 1: Continued. 
<smiles>C=C(C)OCCCCCC</smiles>
Methyl hexanoate (27)<smiles>CC(C)[C@H]1CC[C@@H](C)C[C@H]1O</smiles><smiles>CC1=CC[C@]2(C)[C@@H](C)CC[C@@H](C(C)C)[C@H]2C1</smiles>

$\alpha$-Cubenene (33)

Menthol (32)<smiles>C=C(C)[C@@H]1CC[C@@H](C(=C)C)[C@H](C(=C)C)C1</smiles>

$\beta$-Elemene (38)<smiles>CC1=C2C(CC1)[C@@H](C)CC[C@H]2C(C)C</smiles>

$\alpha$-Gurjunene (39)

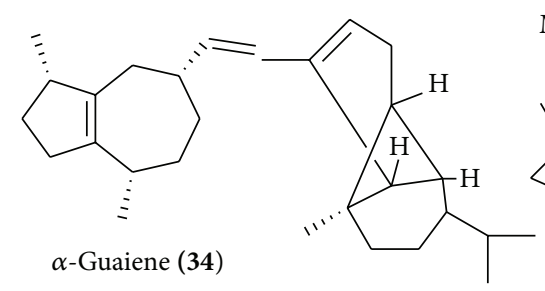

$\alpha$-Ylangene (35)<smiles>COC(=O)c1ccccc1O</smiles>

Methyl salicylate (30)

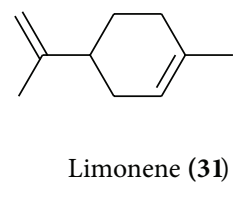

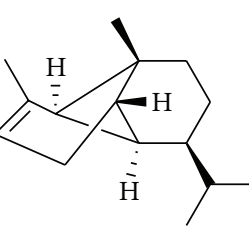

Copaene (36)

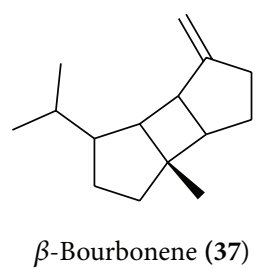

$\beta$-Bourbonene (37)
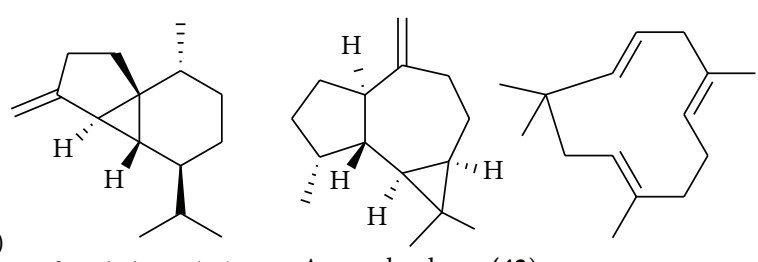

Aromadendrene (42)

$\alpha$-Caryophyllene (43)<smiles>C=C1CCC(C(C)C)C2C=C(C)CCC12</smiles><smiles>C=C1CC[C@H](C(C)C)C2C=C(C)CCC12</smiles><smiles>CC1=C[C@H]2C(C)=CC[C@H](C(C)C)[C@H]2CC1</smiles>

$\alpha$-Muurolene (46)<smiles>CC1=C2CCC(C)C2C2C(CC1)C2(C)C</smiles>

(+)-Ledene (48)<smiles>CCCCCCCCCCCCCCC</smiles>

$\beta$-Cylocital (49)<smiles>C=C[C@]1(C)CC[C@@H](C(C)(C)O)O1</smiles><smiles>C=CCc1ccc(O)c(OC)c1</smiles><smiles>OCC1OC(O)C(O)C(O)C1O</smiles>

$\beta$-D-glucans (61)<smiles>CCCCCCC=O</smiles><smiles>CCCCCCCC=O</smiles>

Octanal (63)

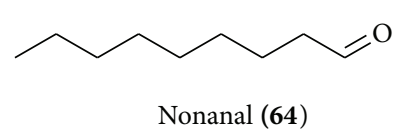<smiles>CCOC(=O)c1ccccc1O</smiles>

Ethyl salicylate (65)

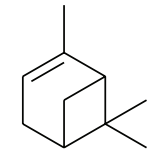

$\alpha$-Pinene (66)

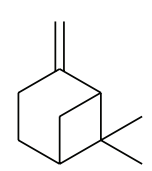

$\beta$-Pinene (67)

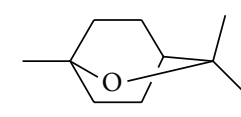

Eucalyptol (68)

(b)

Figure 1: Compounds isolated from leaves, fruits, and barks of F. carica [24-28]. 
anti-inflammatory remedy $[11,12]$. It is commonly referred to as "Fig". Leaves, fruits, and roots of F. carica are used in native medicinal system in different disorders such as gastrointestinal (colic, indigestion, loss of appetite, and diarrhea), respiratory (sore throats, cough, and bronchial problems), inflammatory, and cardiovascular disorders [32, 33]. Fruits of F. carica can be eaten fresh or dried or used as jam. Figs are used as an excellent source of minerals, vitamins, carbohydrates, and dietary fibre because it is fat and cholesterol free and contain high number of amino acids [6, $7,34,35]$. It is also reported that figs have been conventionally used for their therapeutic benefits as laxative, cardiovascular, respiratory, antispasmodic, and anti-inflammatory remedies [36].

The fruit's juice of $F$. carica mixed with honey is used for haemorrhage. In Indian medicine, fruits are used as a mild laxative, expectorant, and diuretic [35]. It is used as aid in liver and spleen diseases. The dry fruit of F. carica is a supplement food for diabetics. It is commercialized in the market as sweet due to its high level of sugars [7]. Fruit paste is applied to swellings, tumours, and inflammation for relieving pain. Twenty-one traditional and current uses of F carica including different ethnopharmacological reports. have been summarized in Table 1.

\section{Biological Activities}

4.1. Antioxidant Activity. F. carica contains many phenolic compounds that play many physiological roles in plants. Some of them are also favourable to human health, since they are able to act as an antioxidant by different ways: reducing agents, hydrogen donators, free radical scavengers, singlet oxygen quenchers, and so forth. Fig fruits of F carica were studied with six commercial fig varieties with different colors (black, red, yellow, and green) for total polyphenols, total flavonoids, antioxidant capacity, and profile of anthocyanins. The antioxidant properties were determined by ferric reducing antioxidant method. Fruits contained the highest levels of polyphenols, flavonoids, and anthocyanins and exhibited the highest antioxidant capacity [31]. Fig fruits of $F$. carica were analyzed for total flavonoids, antioxidant capacity, and profile of anthocyanins [35]. Using RP-LC various concentrations of anthocyanins but similar profiles have been found in all varieties studied. Cyanidin was confirmed as the major aglycone in several studies $[6,34,35]$. NMR data confirmed that cyanidin-3-O-rutinoside (C3R) was the main anthocyanin in all fruits. Color appearance of the fig extract correlated well with total polyphenols, flavonoids, anthocyanins, and antioxidant capacity. C3R contributed $92 \%$ of the total antioxidant capacity of the anthocyanin fraction, and fruits contained highest levels of polyphenols; flavonoids and anthocyanins exhibited the highest antioxidant capacity [35].

4.2. Anticancer Activity. A mixture of 6-O-acyl- $\beta$-d-glucosyl$\beta$-sitosterols has been isolated as an effective cytotoxic agent from fig (F. carica) latex that showed in vitro inhibitory effects on proliferation of various cancer cell lines [39, 41].
4.3. Hepatoprotective Activity. The petroleum ether extract from leaves of F carica was evaluated for hepatoprotective activity on rats treated with $50 \mathrm{mg} / \mathrm{kg}$ of rifampicin orally, and significant reversal of biochemical, histological, and functional changes induced by rifampicin on rats indicated potential hepatoprotective activity [43].

4.4. Hypoglycamic Activity. The leaf extract induced a significant hypoglycamic effect in oral or intraperitoneal administration in streptozotocin-diabetic rats. Weight loss was prevented in treated diabetic rats, and plasma insulin levels considerably altered the survival index. Results indicated that the aqueous extract of F. carica has an obvious hypoglycemic activity [44].

4.5. Hypolipidemic Activity. The leaf extract of F carica could be a beneficial supplement to modulate TG and TC secretion in poultry liver [45]. Eight-weeks-old rooster's liver with high abdominal fat was extracted, sliced, and cultured with increasing concentrations of leaf extract, insulin, and both of them. While insulin extensively increased TG secretion $(0.190 \pm 0.013 \mathrm{mmol} / \mathrm{L}), \mathrm{TG}$ content $(0.523 \pm 0.093 \mathrm{mmol} / \mathrm{L})$, and TC secretion $(1.727 \pm 0.412 \mathrm{mmol} / \mathrm{L})$ beyond the basal level $(P<0.001)$ and when the leaf extract was added, the effects were drastically reduced to the basal level in a concentration-dependent manner $(P<0.001)$.

4.6. Antibacterial Activity and Anti-Fungal Activity. The methanol extract of $F$. carica (MICs, 0.156 to $5 \mathrm{mg} / \mathrm{mL}$; MBCs, 0.313 to $5 \mathrm{mg} / \mathrm{mL}$ ) showed a strong antibacterial activity against oral bacteria. The combination effects of methanol extract with ampicillin or gentamicin were synergistic against oral bacteria that showed that figs could act as a natural antibacterial agent [46]. Hexane, chloroform, ethyl acetate, and methanol extracts of $F$. carica latex were investigated for their antimicrobial proprieties in vitro against five bacterial species and seven strains of fungi using disc-diffusion method. The minimal inhibition concentration (MIC) of the methanol fraction showed a total inhibition against Candida albicans $(100 \%)$ at a concentration of $500 \mu \mathrm{g} / \mathrm{mL}$ and a negative effect against Cryptococcus neoforman; methanolic extract (75\%) strongly inhibited Microsporum canis and ethyl acetate extract at a concentration of $750 \mu \mathrm{g} / \mathrm{mL}$ [47].

4.7. Antipyretic Activity. The ethanol extract of F. carica, at doses of 100, 200, and $300 \mathrm{mg} / \mathrm{kg}$, showed significant dosedependent reduction in normal body temperature, and yeast provoked elevated temperature. The effect extended up to five hrs after drug administration while compared to that of standard antipyretic agent, paracetamol (150 mg/kg.b.wt., p.o.) [48].

4.8. Antituberculosis Activity. The $80 \%$ methanol extract from the leaves of $F$. carica has been screened against Mycobacterium tuberculosis $\mathrm{H} 37 \mathrm{Rv}$ using a colorimetric microplate-based assay. The result exhibited anti-tuberculosis activity with MIC value of $1600 \mu \mathrm{g} / \mathrm{mL}$ [40]. 
TABLE 1: Traditional and current uses of F. carica.

\begin{tabular}{|c|c|c|c|}
\hline Uses & Part & Locality & Reference \\
\hline Cough & Leaf & Malaysia & [37] \\
\hline Colic treatment & Fruit, root, and leaf & unspecified & {$[32,33]$} \\
\hline Indigestion & Fruit, root, and leaf & unspecified & {$[32,33]$} \\
\hline Loss of appetite & Fruit, root, and leaf & unspecified & {$[32,33]$} \\
\hline Antidiarrheal & Fig & unspecified & {$[11,12]$} \\
\hline Metabolic & Fig & unspecified & {$[11,12]$} \\
\hline Cardiovascular & Fig & unspecified & {$[11,12]$} \\
\hline Respiratory & Fig & unspecified & {$[11,12]$} \\
\hline Antispasmodic & Fig & unspecified & {$[11,12,38]$} \\
\hline Anti-inflammatory & Fig & unspecified & {$[11,12]$} \\
\hline Antiplatelet, inflammatory, and gut motility & Fig & Pakistan & {$[38]$} \\
\hline Antioxidant & Fig & unspecified & {$[33]$} \\
\hline Laxative & Fig & unspecified & {$[30]$} \\
\hline Prevention of nutritional anaemia & Leaf & unspecified & {$[27]$} \\
\hline Anthelmintic & Leaf & unspecified & {$[27]$} \\
\hline Irritant potential & Leaf & unspecified & {$[27]$} \\
\hline Nutritive diet & Fruit & Mediterranean countries & {$[31]$} \\
\hline Various drug preparations & Fig fruit & unspecified & {$[39]$} \\
\hline Tuberculosis & Leaf & Malaysia & {$[40]$} \\
\hline Anticancer & Fig & unspecified & {$[41,42]$} \\
\hline Mild laxative, expectorant, and diuretic & Fruit & India & {$[40]$} \\
\hline
\end{tabular}

4.9. Irritant Potential. The methanol extract and isolated triterpenoids from the leaves of $F$. carica were tested for irritant activity. They exhibited irritant potential on mice ears, and calotropenyl acetate, methyl maslinate, and lupeol acetate were the most potent and importunate irritant is which were less than those of euphorbium and close to psoralen. Irritant potential was evaluated by open mouse ear assay [27].

4.10. Nematicidal Activity. Forty different plant species were screened for their nematicidal activity against the nematodes Bursaphelenchus xylophilus, Panagrellus redivivus, and Caenorhabditis elegans. The leaf extract of F. carica showed the strongest nematicidal activity as $74.3,96.2$, and $98.4 \%$ mortality, respectively, within 72 hrs [26].

4.11. Antispasmodic and Antiplatelet Activity. The aqueousethanolic extract of F. carica was investigated for antispasmodic effect on rabbit and antiplatelet effect using ex-vivo model of human platelets. F. carica was tested positive for alkaloids, flavonoids, coumarins, saponins, sterols, and terpenes, and when it was tested in isolated rabbit jejunum $F$. carica $(0.1-3.0 \mathrm{mg} / \mathrm{mL})$ produced relaxation of impulsive and low $\mathrm{K}^{+}-(25 \mathrm{mM})$ induced contraction with insignificant effect on high $\mathrm{K}^{+}(80 \mathrm{mM})$ similar to that caused by cromakalim. Pretreatment of the tissue with glibenclamide caused rightward shift in the curves of low $\mathrm{K}^{+}$but did not cause high potassium ion, while verapamil equally repressed the concentration of potassium ion at both concentrations. F. carica $(0.6$ and $0.12 \mathrm{mg} / \mathrm{mL})$ repressed the adenosine-5-diphosphate and adrenaline-induced human platelet aggregation. That study exhibited spasmolytic activity in the ripe dried fruit of $F$. carica probably mediated through the activation of potassium ion ATP channels along with antiplatelet activity that provided sound pharmacological basis for its medicinal use in the gut motility and inflammatory disorders [37].

4.12. Anthelmintic. The anthelmintic activity of the latex of $F$. carica was investigated in NIH mice naturally infected with Syphacia obvelata, Aspiculuris tetraptera, and Vampirolepis nana. The latex was administered in doses of $3 \mathrm{~mL} / \mathrm{kg} / \mathrm{day}$ during three successive days, was effective in the removal of $S$. obvelata (41.7\%), and did not produce significant elimination of A. tetraptera (2.6\%) and V. nana (8.3\%). High acute toxicity with hemorrhagic enteritis was observed; additional to a weak anthelmintic efficacy, was not recommended the use of this lattice in traditional medicine [49].

4.13. Antimutagenic. Antimutagenic activity of the plant extract of $F$. carica on environmental xenobiotics was investigated. The plant extract decreased the level of mutations induced by $N$-metil- $N^{\prime}$-nitro- $N$-nitrosoguanidine (MNNG) in Vicia faba cells, chlorophyll mutations in Arabidopsis thaliana, and NAF induced mutability in rat marrow cells. The extract verified the ability to decrease the genotoxicity of environmental mutagens [50].

4.14. Anti-HSV. The water extract of the leaves of F carica has been studied on anti-HSV effect and observed on Hep2, BHK21, and PRK cells. The water extract possessed low toxicity and directly killing-virus effect on HSV. The MTC was $0.5 \mathrm{mg} / \mathrm{mL}$, TDO was $15 \mathrm{mg} / \mathrm{mL}$, and TI was $30.0 \mathrm{mg} / \mathrm{mL}$ [51]. 
4.15. Oxidative Stress. Oxidative stress was studied in rats divided into 4 groups: streptozotocin-induced diabetic rats $(n=10)$, diabetic rats that received a single dose of a basic fraction of F carica extract $(n=14)$, diabetic rats that received a single dose of a chloroform fraction of the extract $(n=10)$, and normal rats $(n=10)$. Compared to normal animals, the diabetic animals exhibited extensively higher values for erythrocyte catalyze normalized to haemoglobin levels $(1.5 \pm 0.15$ versus $0.96 \pm 0.18 \mu \mathrm{g} / \mathrm{mg})$ and for plasma vitamin $\mathrm{E}(73.4 \pm 43.9$ versus $12.0 \pm 1.6 \mathrm{mg} / \mathrm{L})$, monounsaturated fatty acids $(0.219 \pm 0.118$ versus $0.067 \pm$ $0.014 \mathrm{mg} / \mathrm{mL}$ ), polyunsaturated fatty acids (PUFA, $0.567 \pm$ 0.293 versus $0.175 \pm 0.040 \mathrm{mg} / \mathrm{mL}$ ), saturated fatty acids $(0.779 \pm 0.262$ versus $0.401 \pm 0.055 \mathrm{mg} / \mathrm{mL})$, and linoleic acid $(0.202 \pm 0.086$ versus $0.106 \pm 0.014 \mathrm{mg} / \mathrm{mL})$. Both $F$. carica fractions showed that they normalize the values of the diabetic animal's fatty acids and plasma vitamin $\mathrm{E}$ values. They showed statistically significant differences as a function of diabetes with the vitamin E/C $18: 2$ ratio being normalized by the administration of the chloroform fraction (to $152.1 \pm$ $80.3 \mu \mathrm{g} / \mathrm{mg}$ ) and the vitamin $\mathrm{A} / \mathrm{C} 18: 2$ ratio being raised relative to the untreated diabetic rats by the administration of the basic fraction $(91.9 \pm 14.5 \mu \mathrm{g} / \mathrm{mg})$. That study confirmed that antioxidant status was affected in the diabetes syndrome, and F. carica extracts showed that they normalize it [52].

\section{Conclusion}

Many interesting biological activities of F carica have been carried out, which can be further explored to make use of them as a healing method for the future. For example, the leaves have shown irritant activity; consequently they can be investigated against parasitic infection and ovicidal activity. The majority of the pharmacological studies which have been carried out on F. carica were conducted with uncharacterized crude extracts; it is difficult to produce the grades of these studies and identify the bioactive metabolites.

Phytochemical research carried out on F. carica has led to the isolation of few classes of plant metabolites. Most of the phytochemical works have been employed on leaves and fruits of F carica, while there is little information on stem and root phenolic profiles. However the vast traditional uses and established pharmacological activities of F. carica point out that an enormous scope still exists for its phytochemical exploration using bioassay-guided isolation. The result of future research in the above mentioned areas will afford a persuasive support for the future clinical uses of F. carica in contemporary remedy.

\section{Conflict of Interests}

The authors confirm they have has no conflict of interests.

\section{Acknowledgments}

This work was supported by the Grants UKM-GGPM-TKP058-2010, UKM-Pharmacy-03-FRGS 0029-2010, and UKMDIPM-006-2011. Special thanks to the Ministry of Higher
Education of Malaysia for providing Commonwealth Scholarship to one of the authors.

\section{References}

[1] D. G. Frodin, "History and concepts of big plant genera," Taxon, vol. 53, no. 3, pp. 753-776, 2004.

[2] N. Rønsted, G. Salvo, and V. Savolainen, "Biogeographical and phylogenetic origins of African fig species (Ficus section Galoglychia)," Molecular Phylogenetics and Evolution, vol. 43, no. 1, pp. 190-201, 2007.

[3] N. Rønsted, G. D. Weiblen, V. Savolainen, and J. M. Cook, "Phylogeny, biogeography, and ecology of Ficus section Malvanthera (Moraceae)," Molecular Phylogenetics and Evolution, vol. 48, no. 1, pp. 12-22, 2008.

[4] M. Dueñas, J. J. Pérez-Alonso, C. Santos-Buelga, and T. Escribano-Bailón, "Anthocyanin composition in fig (Ficus carica L.)," Journal of Food Composition and Analysis, vol. 21, no. 2, pp. 107-115, 2008.

[5] W. S. Jeong and P. A. Lachance, "Phytosterols and fatty acids in fig (Ficus carica var. mission) fruit and tree components," Food Chemistry and Toxicology, vol. 66, pp. 278-281, 2001.

[6] A. Slatnar, U. Klancar, F. Stampar, and R. Veberic, "Effect of drying of figs (Ficus carica L.) on the contents of sugars, organic acids, and phenolic compounds," Journal of Agricultural and Food Chemistry, vol. 59, no. 21, pp. 11696-11702, 2011.

[7] R. Veberic, J. Jakopic, and F. Stampar, "Internal fruit quality of figs (Ficus carica L.) in the Northern Mediterranean Region," Italian Journal of Food Science, vol. 20, no. 2, pp. 255-262, 2008.

[8] J. A. Vinson, L. Zubik, P. Bose, N. Samman, and J. Proch, "Dried fruits: excellent in vitro and in vivo antioxidants," Journal of the American College of Nutrition, vol. 24, no. 1, pp. 44-50, 2005.

[9] J. A. Vinson, "The functional food properties of figs," Cereal Foods World, vol. 44, no. 2, pp. 82-87, 1999.

[10] J. A. Vinson, Y. Hao, X. Su, and L. Zubik, "Phenol antioxidant quantity and quality in foods: vegetables," Journal of Agricultural and Food Chemistry, vol. 46, no. 9, pp. 3630-3634, 1998.

[11] J. A. Duke, M. J. Bugenschutz-godwin, J. Du collier, and P. K. Duke, Hand Book of Medicinal Herbs, CRC Press, Boca Raton, Fla, USA, 2nd edition, 2002.

[12] M. Werbach, Healing with Food, Harper Collins, New York, NY, USA, 1993.

[13] G. Baraket, O. Saddoud, K. Chatti et al., "Sequence analysis ofthe internal transcribed spacers (ITSs) region of the nuclearribosomal DNA, (nrDNA) in fig cultivars (Ficus carica L.)," Scientia Horticulturae, vol. 120, pp. 34-40, 2009.

[14] F. Kjellberg, P.-H. Gouyon, M. Ibrahim, M. Raymond, and G. Valdeyron, "The stability of the symbiosis between dioecious figs and their pollinators: a study of Ficus carica L. and Blastophaga psenes L.," International Journal of Organic Evolution, vol. 41, no. 4, pp. 693-704, 1987.

[15] D. H. Janzen, "How to be a fig," Annual Review of Ecolology and Systematics, vol. 10, pp. 13-51, 1979.

[16] J. T. Weibes, "Co-evolution of figs and their insect pollinators," Annual Review of Ecolology and Systematics, vol. 10, pp. 1-12, 1979.

[17] Flora of North America Association, FNA, 2002, http://www.fna.org/FNA.

[18] California Rare Fruit Growers, "Fig Fruit Facts," 1996, http://www.crfg.org/pubs/ff/fig.html. 
[19] J. Tous and L. Ferguson, "Mediterranean fruits," in Progress in New Crops, J. Janick, Ed., pp. 416-430, ASHS Press, Arlington, Va, USA, 1996.

[20] M. C. Neal, In Gardens of Hawaii, vol. 40, University of Hawaii and Bishop Museum, Honolulu, Hawaii, USA, 1965.

[21] D. Zohary and M. Hopf, Domestication of Plants in the Old World, University Press, Oxford, UK, 3rd edition, 2000.

[22] M. Mars, "Fig (Ficus carica L.) genetic resources and breeding," Acta Horticulturae, vol. 605, pp. 19-27, 2003.

[23] W. L. Wagner, D. R. Herbst, and S. H. Sohmer, Manual of the Flowering Plants of Hawaii, vol. 83, University of Hawaii and Bishop Museum Press, Honolulu, Hawaii, USA, 1999.

[24] A. P. Oliveira, P. Valentão, J. A. Pereira, B. M. Silva, F. Tavares, and P. B. Andrade, "Ficus carica L.: metabolic and biological screening," Food and Chemical Toxicology, vol. 47, no. 11, pp. 2841-2846, 2009.

[25] M. Gibernau, H. R. Buser, J. E. Frey, and M. Hossaert-McKey, "Volatile compounds from extracts of figs of Ficus carica," Phytochemistry, vol. 46, no. 2, pp. 241-244, 1997.

[26] F. Liu, Z. Yang, X. M. Zheng, S. Luo, K. Zhang, and G. Li, "Nematicidal coumarin from F. carica L," Journal of Asia-Pacific Entomology, vol. 14, no. 1, pp. 79-81, 2011.

[27] M. A. Saeed and A. W. Sabir, "Irritant potential of triterpenoids from Ficus carica leaves," Fitoterapia, vol. 73, no. 5, pp. 417-420, 2002.

[28] A. P. Oliveira, L. R. Silva, P. G. D. Pinho et al., "Volatile profiling of Ficus carica varieties by HS-SPME and GC-IT-MS," Food Chemistry, vol. 123, no. 2, pp. 548-557, 2010.

[29] F. Vallejo, J. G. Marín, and F. A. Tomás-Barberán, "Phenolic compound content of fresh and dried figs (Ficus carica L.)," Food Chemistry, vol. 130, no. 3, pp. 485-492, 2012.

[30] O. Ishurd, F. Zgheel, A. Kermagi et al., "Microbial (1-3)- $\beta-D-$ glucans from Libyan figs (Ficus carica)," Carbohydrate Polymers, vol. 58, no. 2, pp. 181-184, 2004.

[31] O. Çalişkan and A. Aytekin Polat, "Phytochemical and antioxidant properties of selected fig (Ficus carica L.) accessions from the eastern Mediterranean region of Turkey," Scientia Horticulturae, vol. 128, no. 4, pp. 473-478, 2011.

[32] I. H. Burkill, A Dictionary of the Economic Products of Malay Peninsular, Ministry of Agriculture of Malaysia, 1935.

[33] O. Penelope, Great Natural Remedies, Kyle Cathic Limited, New York, NY, USA, 1997.

[34] R. Veberic, M. Colaric, and F. Stampar, "Phenolic acids and flavonoids of fig fruit (Ficus carica L.) in the northern Mediterranean region," Food Chemistry, vol. 106, no. 1, pp. 153-157, 2008.

[35] A. Solomon, S. Golubowicz, Z. Yablowicz et al., "Antioxidant activities and anthocyanin content of fresh fruits of common fig (Ficus carica L.)," Journal of Agricultural and Food Chemistry, vol. 54, no. 20, pp. 7717-7723, 2006.

[36] P. M. Guarrera, "Traditional phytotherapy in Central Italy (Marche, Abruzzo, and Latium)," Fitoterapia, vol. 76, no. 1, pp. 1-25, 2005.

[37] S. Mohamad, N. M. Zin, H. A. Wahab et al., "Antituberculosis potential of some ethnobotanically selected Malaysian plants," Journal of Ethnopharmacology, vol. 133, no. 3, pp. 1021-1026, 2011.

[38] A. H. Gilani, M. H. Mehmood, K. H. Janbaz, A.-U. Khan, and S. A. Saeed, "Ethnopharmacological studies on antispasmodic and antiplatelet activities of Ficus carica," Journal of Ethnopharmacology, vol. 119, no. 1, pp. 1-5, 2008.
[39] S. D. Yancheva, S. Golubowicz, Z. Yablowicz, A. Perl, and M. A. Flaishman, "Efficient agrobacterium-mediated transformation and recovery of transgenic fig (Ficus carica L.) plants," Plant Science, vol. 168, no. 6, pp. 1433-1441, 2005.

[40] S. S. Khadabadi, N. Y. Gond, N. B. Ghiware, and G. R. Shendarkar, "Hepatoprotective effect of Ficus carica leaf in chronic hepatitis," Indian Drugs, vol. 44, no. 1, pp. 54-57, 2007.

[41] S. Rubnov, Y. Kashman, R. Rabinowitz, M. Schlesinger, and R. Mechoulam, "Suppressors of cancer cell proliferation from fig (Ficus carica) resin: isolation and structure elucidation," Journal of Natural Products, vol. 64, no. 7, pp. 993-996, 2001.

[42] C. Perez, J. R. Canal, J. E. Campillo, A. Romero, and M. D. Torres, "Hypotriglyceridaemic activity of Ficus carica leaves in experimental hypertriglyceridaemic rats," Phytotherapy Research, vol. 13, pp. 188-191, 1999.

[43] N. Y. Gond and S. S. Khadabadi, "Hepatoprotective activity of Ficus carica leaf extract on rifampicin-induced hepatic damage in rats," Indian Journal of Pharmaceutical Sciences, vol. 70, no. 3, pp. 364-366, 2008.

[44] C. Perez, E. Domínguez, J. M. Ramiro, A. Romero, J. E. Campillo, and M. D. Torres, "A study on the glycaemic balance in streptozotocin-diabetic rats treated with an aqueous extract of Ficus carica (fig tree) leaves," Phytotherapy Research, vol. 10, no. 1, pp. 82-83, 1998.

[45] F. Asadi, M. Pourkabir, R. Maclaren, and A. Shahriari, "Alterations to lipid parameters in response to fig tree (Ficus carica) leaf extract in chicken liver slices," Turkish Journal of Veterinary and Animal Sciences, vol. 30, no. 3, pp. 315-318, 2006.

[46] M.-R. Jeong, H.-Y. Kim, and J.-D. Cha, "Antimicrobial activity of methanol extract from Ficus carica leaves against oral bacteria," Journal of Bacteriology and Virology, vol. 39, no. 2, pp. 97-102, 2009.

[47] H. L. Aref, K. B. H. Salah, J. P. Chaumont, A. Fekih, M. Aouni, and K. Said, "In vitro antimicrobial activity of four Ficus carica latex fractions against resistant human pathogens (antimicrobial activity of Ficus carica latex)," Pakistan Journal of Pharmaceutical Sciences, vol. 23, no. 1, pp. 53-58, 2010.

[48] V. V. Patil, S. C. Bhangale, and V. R. Patil, "Evaluation of antipyretic potential of Ficus carica leaves," International Journal of Pharmaceutical Sciences Review and Research, vol. 2, no. 2, pp. 48-50, 2010.

[49] A. De Amorin, H. R. Borba, J. P. P. Carauta, D. Lopes, and M. A. Kaplan, "Anthelmintic activity of the latex of Ficus species," Journal of Ethnopharmacology, vol. 64, no. 3, pp. 255-258, 1999.

[50] R. A. Agabeǐli and T. E. Kasimova, "Antimutagenic activity of Armoracia rusticana, Zea mays and Ficus carica plant extracts and their mixture," Tsitologiia I Genetika, vol. 39, no. 3, pp. 7579, 2005.

[51] G. Wang, H. Wang, Y. Song, C. Jia, Z. Wang, and H. Xu, "Studies on anti-HSV effect of Ficus carica leaves," Zhong Yao Cai, vol. 27, no. 10, pp. 754-756, 2004.

[52] C. Pèrez, J. R. Canal, and M. D. Torres, "Experimental diabetes treated with ficus carica extract: effect on oxidative stress parameters," Acta Diabetologica, vol. 40, no. 1, pp. 3-8, 2003. 


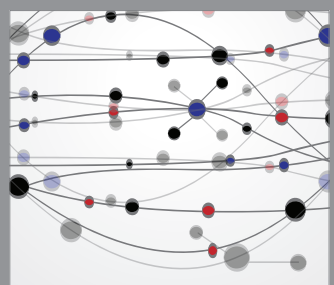

The Scientific World Journal
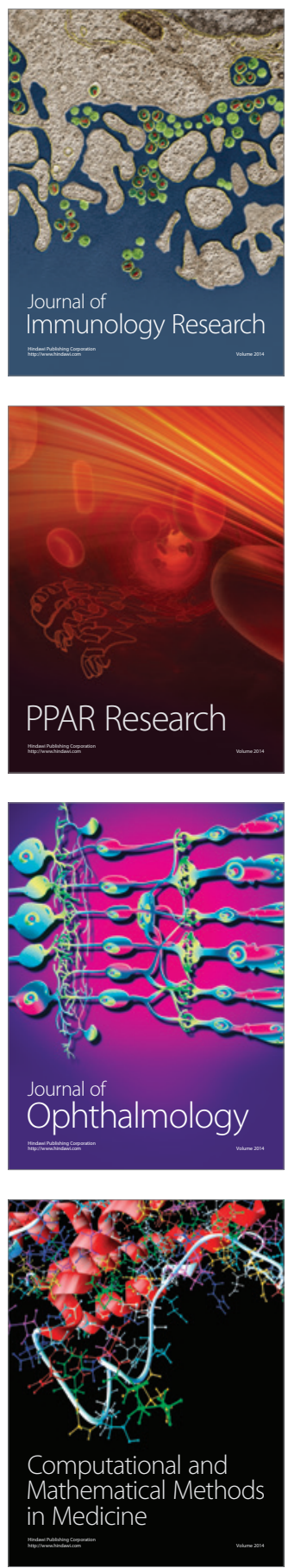

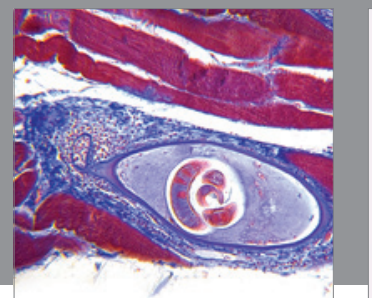

Gastroenterology

Research and Practice
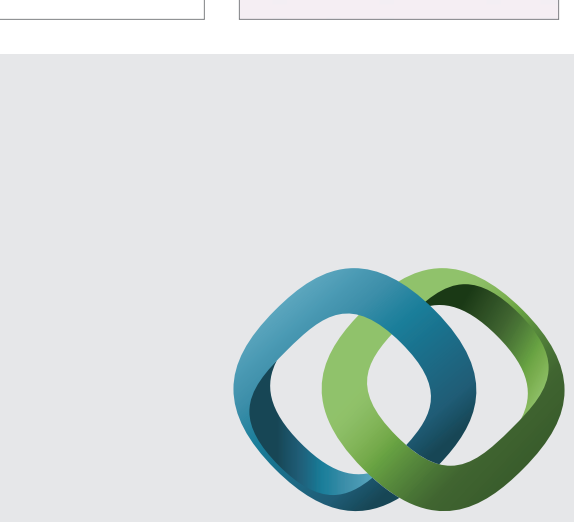

\section{Hindawi}

Submit your manuscripts at

http://www.hindawi.com
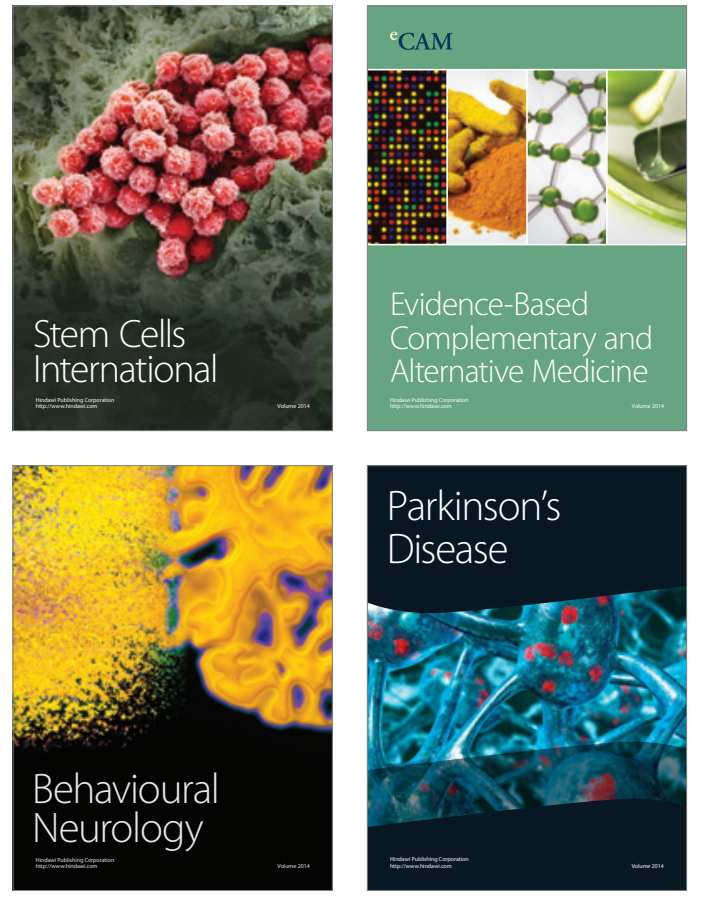
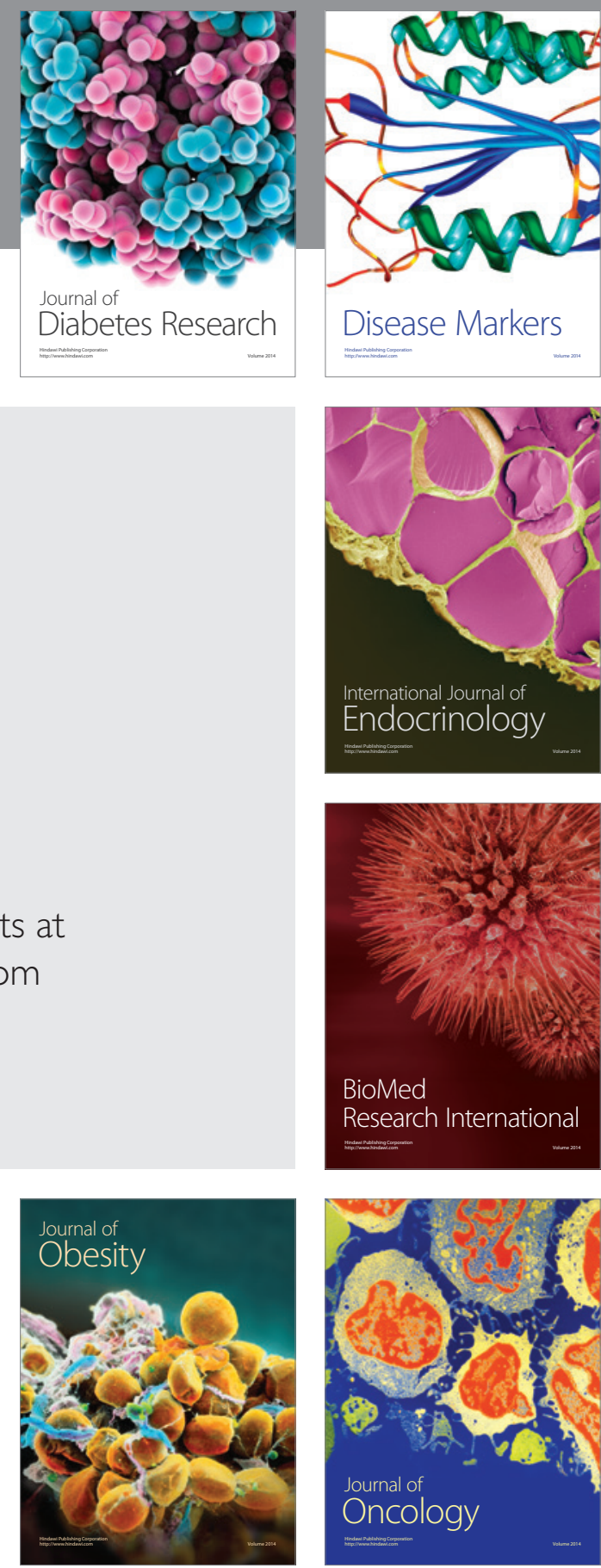

Disease Markers
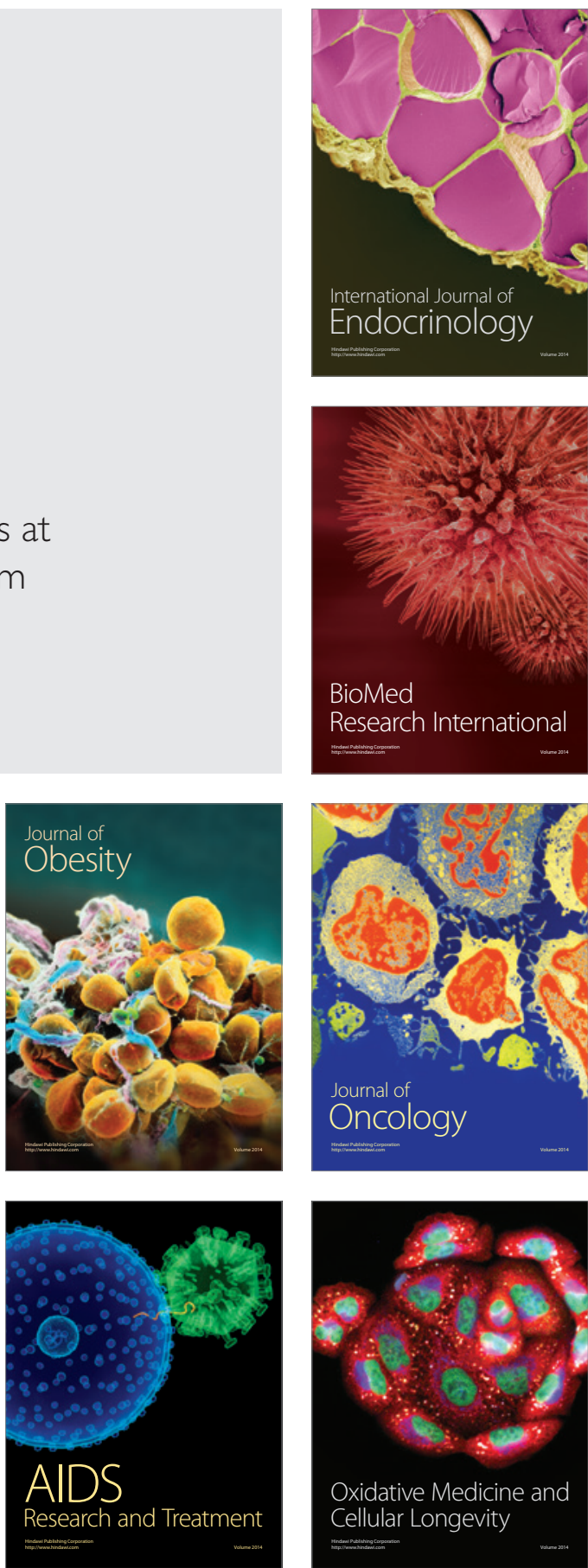